\title{
ANALYSIS OF THE EFFECT OF GENERATING-DRAWING MOVEMENT Oleh Harziko
}

\begin{abstract}
The terminal is a center for the entry and exit of vehicles that have a high intensity in attracting movement as the generation and towing of the vehicle interacts to its destination. Based on the generation, which is generated based on the stages of movement generation, which produces a relationship model that connects land use parameters with the number of movements to a zone. Therefore, this study aims to identify the tank-pull modeling as the movement of transportation of vehicles, people, or goods per unit time. which serves as the center of community activities, the case study of the Presidential Instruction Market Terminal in the city of Namlea in this study there are two kinds of variables, namely $a$. The independent variables consist of land use systems and transportation systems, b. The dependent variable is the number of transportation needs calculated from the number of traffic flows of passengers, goods, and vehicles on the highway per unit time. Generation and withdrawal based on analysis at the Namlea Inpres market terminal on weekdays fluctuates from 17.00/hour to 77.80/hour. The highest pull-out occurred at 11:00-12:00 at 77.80 pcu/hour, while the lowest was at 17:00-18:00 at 17:00 pcu/hour. the attractiveness of the Inpres Namlea market terminal on holidays fluctuated from $23.40 \mathrm{pcu} / \mathrm{hour}$ to $72.60 \mathrm{pcu/hour}$. The highest draw-up occurred at 11:00-12:00 at 72.60 pcu/hour, while the lowest revitalization occurred at 17:00-18:00 at 23.40 pcu/hour.
\end{abstract}

Keywords: awakening; pull; Terminal; Namlea Inpres Market

\section{INTRODUCTION}

The existence of a terminal in the city of Namlea, makes traffic activities in the city of Namlea become increasingly congested so that it affects the level of road service. This land use change will cause trip generation and attraction which will increase the traffic volume around the terminal. The addition of a large volume can be a new problem for congestion around the terminal.

In this regard, the authors conducted research on the analysis of the influence of the existence of a terminal in the city of Namlea. Transportation can be interpreted as an effort, moving, determining, or determining an object from other places, in other places it is more useful or can be useful for certain purposes (Miro, 2002).

Transportation is an inseparable part of human life. Human activities and their various needs cannot be fulfilled by just staying in one place. Means of transportation help humans in traveling time from one place to the destination.

According to Ofyar Z. Tamin, the basic goal of transportation planners is to estimate the amount and location of transportation needs (eg determining the total movement, both for public transport and private transport) in the future or plans to be used for various transportation planning investment policies.

The systems approach to transport planning can be described in terms of a macro transport system consisting of several micro transport systems. The transportation system as a whole (macro) can solve several smaller (micro) systems, namely; (a) system of activities; (b) transportation infrastructure network system; (c) traffic movement system; and (d) institutional system. Each of these systems are interrelated with each other.

Movement is the transition from one place to another by means of means. A city can be viewed as a place where activities occur or as a pattern of land use. The location where the activity is carried out will affect humans and human activities will affect the location where the activity takes place.

Movement is strongly influenced by the purpose or intent of a trip and the time of the trip. The purpose of the trip can be in the form of educational, economic, social activities, and so on. 
Travel times also vary depending on the purpose of the trip. For example, in the morning the travel time increases due to the purpose of the trip to school or to work.

According to Ofyar Z. Tamin, traffic movement arises because of the process of fulfilling needs. We need to move because our needs cannot be met where we are. Each land use or activity system (the first micro system) has a certain type of activity that will generate movement and will attract movement in the process of meeting needs.

Hutchinson in Wika. S (2009) classifies movements into two main groups, namely homebased trips and non-home-based trips. Home-based movement is a journey that originates from home to the desired destination and is usually permanent in nature, including movement to work, shopping, and school. Non-home-based movement is travel originating from a place other than home, including movement between work and shop, business movement between two workplaces.

Based on the background above, several problems can be formulated as follows: How is the Influence of Generation-Attractive on the movement of land transportation modes from downtown Namlea to outside the city? and How is the road performance around Namlea City Inpres Market Terminal after the terminal is operational? while the research objectives

The aims of this study are: To determine the performance of the road around the Namlea City Inpres Market Terminal after the terminal operates and to determine the magnitude of the attraction generation value that occurs at the Namlea Inpres Market Terminal.

\section{Daftar Pustaka}

\section{Daftar Pustaka}

Sam, B., Iye, R., Ohoibor, M., Umanailo, M. C. B., Rusdi, M., Rahman, A. B. D., \& Hajar, I. (2019). Female Feminism in the Customary Island of Buru. Int. J. Sci. Technol. Res, $8(8), 1877-1880$.

Susiati, S., Iye, R., \& Suherman, L. O. A. (2019). Hot Potatoes Multimedia Applications in Evaluation of Indonesian Learning In SMP Students in Buru District. ELS Journal on Interdisciplinary Studies in Humanities, 2(4), 556-570.

Susiati, S., Iye, R., \& Suherman, L. O. A. (2019). Hot Potatoes Multimedia Applications in Evaluation of Indonesian Learning In SMP Students in Buru District. ELS Journal on Interdisciplinary Studies in Humanities, 2(4), 556-570.

Iye, R., \& Susiati, S. (2018). NILAI EDUKATIF DALAM NOVEL SEBAIT CINTA DI BAWAH LANGIT KAIRO KARYA MAHMUD JAUHARI ALI (Educative Values in Sebait Cinta di Bawah Langit Kairo by Mahmud Jauhari Ali). Sirok Bastra, 6(2), 185-191.

Susiati, S. (2018). Homonim bahasa kepulauan tukang besi dialek kaledupa di kabupaten wakatobi [the homonymon of tukang besi island languange in kaledupa dialect at wakatobi regency]. Totobuang, 6(1), 109.

Susiati, S. (2020). The Concept Of Togetherness In The Films" Aisyah Biarkan Kami Bersaudara" By Herwin Novianto. 
Nurhayati, N., \& Said, I. (2019). Emosi Verbal Suku Bajo Sampela. Sosial Budaya, 16(2), 114126.

Susiati, S., \& Iye, R. (2018). Kajian Geografi Bahasa dan Dialek di Sulawesi Tenggara: Analisis Dialektometri. Gramatika: Jurnal Ilmiah Kebahasaan dan Kesastraan, 6(2), 137-151.

Susiati, S. The Concept Of Togetherness In The Films" Aisyah Biarkan Kami Bersaudara" By Herwin Novianto.

Iye, R., Susiati, S., \& Karim, K. (2020). Citra Perempuan dalam Iklan Sabun Shinzui. Sang Pencerah: Jurnal Ilmiah Universitas Muhammadiyah Buton, 6(1), 1-7.

Susiati, S. (2020). The Concept Of Togetherness In The Films" Aisyah Biarkan Kami Bersaudara" By Herwin Novianto.

Susiati, S. (2020). Eksistensi Manusia Dalam Film" Aisyah Biarkan Kami Bersaudara" Karya Herwin Novianto.

Iye, R. (2018). Tuturan dalam Prosesi Lamaran Pernikahan di Tomia Kabupaten Wakatobi. Jurnal Totobuang, 6(2).

Susiati, S. Konsep Pertentangan Dalam Film" Aisyah Biarkan Kami Bersaudara" Karya Herwin Novianto.

Wael, A., Setiaji, A. B., Pannyiwi, R., Lapandewa, L., Asshagab, S. M. N., Jouhari, B., ... \& Umanailo, B. (2019). „Bupolo“e Motion Reading. Int. J. Sci. Technol. Res, 8(9), 21542158 .

Susiati, S. (2020). Konsep Kebersamaan Dalam Film" Aisyah Biarkan Kami Bersaudara" Karya Herwin Novianto.

Wael, A., Setiaji, A. B., Pannyiwi, R., Lapandewa, L., Asshagab, S. M. N., Jouhari, B., ... \& Umanailo, B. "Bupolo" Motion Reading.

Iye, R. H. (2019). NILAI-NILAI MORAL DALAM TOKOH UTAMA PADA NOVEL SATIN MERAH KARYA BRAHMANTO ANINDITO DAN RIE YANTI. TELAGA BAHASA,(7), 2, 195-206.

Iye, R. Jl Prof Dr HAR Basalamah No, and Namlea-Kab Buru.". TUTURAN DALAM PROSESI LAMARAN PERNIKAHAN DI TOMIA KABUPATEN WAKATOBI." Kontemporer. Bandung: PT Remaja.

Iye, R., Tenriawali, A. Y., Susiati, A., \& Buton, D. (2020). Makna dan Fungsi Emosi Mahasiswa Kota Baubau dalam Ranah Demonstrasi: The Meaning And Emotional Function Of Students Of Baubau City In The Demonstration Plan. Uniqbu Journal of Social Sciences, 1(1), 25-37.

Referen, B. Konsep teori de Saussure ini dikembangkan lagi oleh Richard dan Ogdent (dalam Chaer, 1994: 287) Dalam sebuah bagan makna berupa segi tiga yang menghubungkan 
tiga komponen makna, yaitu bentuk, konsep, dan referen. Bagannya adalah sebagai berikut.

Masiri, R., Iye, R., Harziko, H., Malik, S., \& Karim, K. (2020). ERROR ANALYSIS IN STUDENTS'CLASSROOM DISCUSSION AT MTS LKMD WAEMOLI:(Analisis Kesalahan Berbahasa Dalam Diskusi Siswa Kelas VIII MTS LKMD Waemoli). Uniqbu Journal of Social Sciences, 1(2), 56-62.

Susiati, S. (2020). Semantik: Teori Semantik, Relasi Makna, Marked, Dan Unmarked.

Iye, R., Tenriawali, A. Y., Susiati, A., \& Buton, D. (2020). Makna dan Fungsi Emosi Mahasiswa Kota Baubau dalam Ranah Demonstrasi: The Meaning And Emotional Function Of Students Of Baubau City In The Demonstration Plan. Uniqbu Journal of Social Sciences, 1(1), 25-37.

Susiati, S., Masniati, A., \& Iye, R. (2021). Kearifan Lokal Dalam Perilaku Sosial Remaja Di Desa Waimiting Kabupaten Buru. Sang Pencerah: Jurnal Ilmiah Universitas Muhammadiyah Buton, 7(1), 8-23.

Iye, R., Tenriawali, A. Y., Susiati, A., \& Buton, D. (2020). Makna dan Fungsi Emosi Mahasiswa Kota Baubau dalam Ranah Demonstrasi: The Meaning And Emotional Function Of Students Of Baubau City In The Demonstration Plan. Uniqbu Journal of Social Sciences, 1(1), 25-37.

BAUBAU, T. O. FOLLOW THE EVENTS IN THE INDONESIAN LANGUAGE EXPRESSIVE SAID TRANSACTION IN THE TRADITIONAL MARKET.

Iye, R. (2018). Tuturan emosi mahasiswa kota baubau dalam ranah demonstrasi.

Susiati, S., Masniati, A., \& Iye, R. (2021). Kearifan Lokal Dalam Perilaku Sosial Remaja Di Desa Waimiting Kabupaten Buru. Sang Pencerah: Jurnal Ilmiah Universitas Muhammadiyah Buton, 7(1), 8-23.

Susiati, S. Fenomena Tuturan Emosi Verbal Bahasa Indonesia Suku Bajo Sampela.

Iye, Risman, A. Yusdianti Tenriawali, Azwan Susiati, and Darwis Buton. "MAKNA DAN FUNGSI EMOSI MAHASISWA KOTA BAUBAU DALAM RANAH DEMONSTRASI: THE MEANING AND EMOTIONAL FUNCTION OF STUDENTS OF BAUBAU CITY IN THE DEMONSTRATION PLAN." Uniqbu Journal of Social Sciences 1, no. 1 (2020): 25-37.

Harziko, H., Said, I. M., \& Darwis, K. (2018). FOLLOW THE EVENTS IN THE INDONESIAN LANGUAGE EXPRESSIVE SAID TRANSACTION IN THE TRADITIONAL MARKET TOWN OF BAUBAU. JURNAL ILMU BUDAYA, 6(1).

Susiati, S., Tenriawali, A. Y., Nursin, N., Nacikit, J., \& Mukadar, S. (2020). NILAI EDUKASI DALAM NOVEL PARTIKEL KARYA DEWI LESTARI:(The Value of Education in Particle Novels by Dewi Lestari). Uniqbu Journal of Social Sciences, 1(3), 176-183. 
Yusnan, M., Kamasiah, R. I., Karim, H., \& Bugis, R. (2020). Alih Kode dan Campur Kode pada Novel Badai Matahari Andalusia Karya Hary El-parsia: Transfer Code And Mix Code In Novels Badai Matahari Andalusia Karya Hary El-parsia. Uniqbu Journal of Social Sciences, 1(1), 1-12.

Yusnan, M., Kamasiah, R. I., Karim, H., \& Bugis, R. (2020). ALIH KODE DAN CAMPUR KODE PADA NOVEL BADAI MATAHARI ANDALUSIA KARYA HARY ELPARSIA: Transfer code and mix code in Novels Badai Matahari Andalusia Karya Hary El-Parsia. Uniqbu Journal of Social Sciences, 1(1), 1-12.

Iye, R. WRITING SKILLS IN SMP USWATUN HASANAH. BURU DISTRICT.

Karim, A. B., \& Yusnan, M. Aspek Spiritual Dalam Novel Tuhan Izinkan Aku Menjadi Pelacur Karya Muhidin M Dahlan: Spiritual Aspects in the Lovely of God Let Me Become a Property of Muhidin M Dahlan. Uniqbu Journal of Social Sciences, 1(1), 61-71.

Bin-Tahir, S. Z., Suriaman, A., Hanapi, H., Iye, R., \& Umanailo, M. C. B. (2020). Development of Buru Local Language Conversation Material Based on the CommunicativeInteractive Approach for Elementary School Students. Solid State Technology, 63(2s).

Iye, R. WRITING SKILLS IN SMP USWATUN HASANAH. BURU DISTRICT.

Susiati, S., Tenriawali, A. Y., Nursin, N., Nacikit, J., \& Mukadar, S. (2020). NILAI EDUKASI DALAM NOVEL PARTIKEL KARYA DEWI LESTARI:(The Value of Education in Particle Novels by Dewi Lestari). Uniqbu Journal of Social Sciences, 1(3), 176-183.

Karim, A. B., \& Yusnan, M. (2020). Aspek Spiritual Dalam Novel Tuhan Izinkan Aku Menjadi Pelacur Karya Muhidin M Dahlan: Spiritual Aspects in the Lovely of God Let Me Become a Property of Muhidin M Dahlan. Uniqbu Journal of Social Sciences, 1(1), 6171.

Andini, K. NILAI BUDAYA SUKU BAJO SAMPELA DALAM FILM THE MIRROR NEVER LIES KARYA KAMILA ANDINI.

Umanailo, M. C. B., Hentihu, I., Umanailo, R., Nawawi, M., Pulhehe, S., Ohoibor, M., ... \& MANGESA, R. (2018). Comprehension To Village.

Andini, K. NILAI BUDAYA SUKU BAJO SAMPELA DALAM FILM THE MIRROR NEVER LIES KARYA KAMILA ANDINI.

Umanailo, M., Hentihu, I., Umanailo, R., Nawawi, M., Pulhehe, S., Ohoibor, M., ... \& Musa, M. N. D. (2017). Comprehension To Village (No. yuavq). Center for Open Science.

Susiati, S. (2020). Nilai Budaya Suku Bajo Sampela Dalam Film The Mirror Never Lies Karya Kamila Andini.

Susiati, S., \& Iye, R. (2018). Kajian Geografi Bahasa dan Dialek di Sulawesi Tenggara: Analisis Dialektometri. Gramatika: Jurnal Ilmiah Kebahasaan dan Kesastraan. 6 (2), 137-151. 
Rabadia, E. S. O., \& Hanapi, H. STUDENTS'WRITING SKILL THROUGH CLUSTERING TECHNIQUE.

Sam, B., Iye, R., Ohoibor, M., \& Umanailo, M. CB, Rusdi, M., Rahman, ABD, \& Hajar, I.(2019). Female Feminism in the Customary island of Buru, 1877-1880.

Lafamane, F. (2020). Perkembangan Teori Sastra (suatu Pengantar).

Bin Tahir, S. Z., Iye, R., Tenriawali, A. Y., Karim, Z. Z. Z., \& Umanailo, M. C. B. (2020, March). Cia-cia vocational inventoryization in Buru district. In Proceedings of the International Conference on Industrial Engineering and Operations Management (No. 0, pp. 25092518).

Nurlatu, J., Bugis, R. K., Karim, K., Azwan, A., \& Iye, R. (2020). Penggunaan Dieksis Sopan Santun Mahasiswa Universitas Iqra Buru. Jurnal Ilmiah FONEMA: Jurnal Edukasi Bahasa dan Sastra Indonesia, 3(2), 154-164.

Susiati, S. PERWUJUDAN SIMILE OLEH MERARI SIREGAR DALAM NOVEL AZAB DAN SENGSARA.

Susiati, S. Dialektometri Segitiga: Hubungan Kekerabatan Bahasa Di Sulawesi Tenggara (Bahasa Wakatobi, Bahasa Cia-Cia, Bahasa Pancana, Bahasa Kioko, Bahasa Tolaki).

Lafamane, F. (2020). Perkembangan Teori Sastra (suatu Pengantar).

Susiati, S., \& Mufidati, E. (2020). An Indonesian National English Textbook for Secondary Level: Is It Qualified Enough?. Jurnal VARIDIKA, 32(1), 118-124.

Yulismayanti, H., Iye, R., \& Susiati, S. Z. B. T. (2020). VARIATIVE METHOD IN IMPROVING STUDENT LEARNING MOTIVATION IN PANDEMIC COVID-19 SITUATIONS. Journal of Critical Reviews, 7(5), 1584-1595.

Susiati, S. Dialektometri Segitiga: Hubungan Kekerabatan Bahasa Di Sulawesi Tenggara (Bahasa Wakatobi, Bahasa Cia-Cia, Bahasa Pancana, Bahasa Kioko, Bahasa Tolaki).

Yulismayanti, H., Iye, R., \& Susiati, S. Z. B. T. (2020). VARIATIVE METHOD IN IMPROVING STUDENT LEARNING MOTIVATION IN PANDEMIC COVID-19 SITUATIONS. Journal of Critical Reviews, 7(5), 1584-1595.

Lafamane, Felta. "KAJIAN STILISTIKA (Komponen Kajian Stilistika)." (2020).

Susiati, Susiati. "Makian Bahasa Wakatobi Dialek Kaledupa." (2020).

Bassalamah, J. P. D. H. (2020). MAKIAN BAHASA WAKATOBI DIALEK KALEDUPA.

Susiati, S. risman iye. 2020.“. Dialektometri Segitiga: Hubungan Kekerabatan Bahasa Di Sulawesi Tenggara (bahasa Wakatobi, Bahasa Cia-cia, Bahasa Pancana, Bahasa Kioko, Bahasa Tolaki)." OSF Preprints. July, 21. 
Yulismayanti, Y., Harziko, H., \& Irmawati, A. Kemampuan Menemukan Nilai Edukatif Dalam Cerpen Juru Masak Karya Damhuri Muhammad Siswa Kelas X SMA Negeri 12 Buru:(the Avility to Find Educative Values in Story of Master Teacher Work of Damhuri Muhammad at SMP 12 Buru). Uniqbu Journal of Social Sciences, 1(2), 35-48.

Yulismayanti, Y., Harziko, H., \& Irmawati, A. (2020). Kemampuan Menemukan Nilai Edukatif Dalam Cerpen Juru Masak Karya Damhuri Muhammad Siswa Kelas X SMA Negeri 12 Buru:(the Avility to Find Educative Values in Story of Master Teacher Work of Damhuri Muhammad at SMP 12 Buru). Uniqbu Journal of Social Sciences, 1(2), 35-48.

Susiati, S. (2020). Pentingnya Melestarikan Bahasa Daerah.

UNIQBU, P. (2019). TUTURAN EMOSI MAHASISWA KOTA BAU BAU.

Susiati, Y. T. Risman Iye. A. Kesantunan Imperatif Bahasa Indonesia Suku Bajo Sampela: Balai Pembinaan dan Pengembangan Bahasa. 2018. Kongres Bahasa Indonesia (No. 12, pp. 1-6). Report.I

Tenriawali, A. Y., Azwan, R. B., Taufik, M., Harziko, R. I., \& Bin-Tahir, S. Z. Politeness of Language Use amongst Millennial Generation in Namlea City.

Umanailo, M. C. B. (2021). Politeness of Language Use amongst Millennial Generation in Namlea City.

Nurlatu, J., Bugis, R. K., \& Iye, R. Penggunaan Dieksis Sopan Santun Mahasiswa Universitas Iqra Buru.

Hanapi, H. Gaya Bahasa pada Novel Piano dalam Kotak Kaca Karya Agnes Jessica. Uniqbu Journal of Social Sciences, 1(1), 344007. 